\title{
Enhancing English Proficiency and Communication Skills Among Malaysian Graduates through Training and Coaching
}

\author{
Seetha Nesaratnam (Corresponding author) \\ Dept. of Training and Development, Dale Carnegie Training Malaysia \\ Pusat Perdagangan, Phileo Damansara, Petaling Jaya, Malaysia \\ E-mail: seetha@dalecarnegie.com.my \\ Wan Hisham Wan Salleh \\ Dept. of Training and Development, Dale Carnegie Training Malaysia \\ Pusat Perdagangan, Phileo Damansara, Petaling Jaya, Malaysia \\ E-mail: whisham@dalecarnegie.com.my
}

Yi Von Foo

Dept. of Training and Development, Dale Carnegie Training Malaysia

Pusat Perdagangan, Phileo Damansara, Petaling Jaya, Malaysia

E-mail: yivonfoo@dalecarnegie.com.my

Wan Mahmud Wan Syazwan Wan Hisham

Dept. of Training and Development, Dale Carnegie Training Malaysia

Pusat Perdagangan, Phileo Damansara, Petaling Jaya

E-mail: Mahmud@dalecarnegie.com.my

Received: July 26, 2020 Accepted: August 22, 2020 Published: September 15, 2020

doi:10.5296/ijld.v10i4.17875 URL: https://doi.org/10.5296/ijld.v10i4.17875 


\section{Abstract}

Employability of graduates has become a matter of grave concern in Malaysia where the high unemployment rate of graduates is said to be a result of poor English communication skills. English communication plays an important role in an organisation and is said to enhance efficiency and productivity. English communication is therefore, a critical skill for graduates seeking employment, regardless of position or industry. The importance of English communication skills for graduates in the Malaysian private sector and recommendations for improvement initiatives were the focal points of this study. Data was collected from in-depth interviews with 10 employers in the private sector who are in leadership positions, who recruit and manage graduates. The interview transcripts were analysed using ATLAS.ti a Computer Assisted Qualitative Data AnalysiS (CAQDAS) and the findings of the study strongly indicate that employers in the private sector place high value on English communication competency. The results also revealed that mastery of this skill enhances employability of graduates and also creates opportunities for career advancement. The findings further point towards the importance of deeper collaboration between Higher Education Institutions (HEIs) and industry, graduate training and coaching.

Keyword: Employability, English communication, skills, graduates, collaboration, coaching and training

\section{Introduction}

The emerging importance of the English language as the lingua franca of the business community in the Asian region has rendered English proficiency and communications skills key employability requirement (Ting et al., 2017; Truong, Laura, \& Shaw, 2018). Article 34 of the ASEAN Charter 2009, states that the 'working language of ASEAN shall be English' (Kirkpatrick, 2012). English proficiency and communication are therefore key enablers for businesses in the ASEAN region to remain competitive in the global market (Jobstreet.com, 2015; Singaravela \& Paramasivam, 2016). To achieve this, employees need to be able to communicate effectively in English with colleagues and business partners from diverse backgrounds, domestically and internationally. English is no longer relegated to a mere tool for establishing global partnerships, but is now being widely used in daily operations amongst co-workers (Thomas, Piquette, \& McMaster, 2016). Singh (2013), argued that English and communication play vital roles in organisations; in meetings and discussions and enhances both efficiency and productivity. English and communication are therefore, a critical skills for graduates seeking employment, regardless of position or industry (Singaravela \& Paramasivam, 2016). In this $21^{\text {st }}$ century globalised economy, a graduate's proficiency and ability to communicate in English in the workplace, has become a key requirement of employers. Ismail (2011) carried out research on 3,025 Malaysian graduates, and the findings of the study showed evidence that graduates with proficiency in English communication are more employable.

In Malaysia, the English language still remains a key business language and mastery of it is undeniably helpful in the employment process. The employers naturally have a high expectancy of the graduates to be competent in their respective fields of education yet 
competency in English communication is still a crucial proviso in securing gainful employment (Ismail, Yusoff, \& Sieng, 2011; Jobstreet.com, 2015; Pandey \& Pandey, 2014).

In response to the growing importance of the English language, Universities in Malaysia have included a range of English courses into the curriculum, such as English for Academic Purposes (EAP) and English for Occupational Purposes (EOP). General English language proficiency courses are also offered to students who are unable to meet the English proficiency requirements of a programme. EAP is aimed at preparing students to familiarise with the language conventions of a specific discipline. EOP courses however, cater for students who register for professional degrees with the aim to prepare students for their professional and workplace setting. However, despite initiatives to provide quality courses and teaching the decline of its English proficiency among Malaysian universities graduates continue to be in the limelight (Park \& Spolsky, 2017). The Malaysian government has attempted to strengthen graduates' skills through various soft skills and English language training programmes such as the Graduate Career Accelerated Programme (GCAP), The Graduate Employability Management Scheme (GEMS) and the 1Malaysia Training Scheme (SL1M) to name a few. The key focus of these programmes is to up-skill fresh graduates in English communication and other soft skills to help them find suitable professional employment. A more structured internship programme was also initiated by the Ministry of Higher Education and implemented into the curriculum of HEIs as one of the ways to enhance employability among local graduates. Unfortunately, in Malaysia, universities do not have strong connections with industry or extensive information about organisations that provide such opportunities (Alias, 2017) hence this has hampered the internship programme objectives. In fact according to The World Bank's Knowledge Economy Index, Malaysia ranks 48 out of 145 countries in innovative capability as a result of the lack of HEI and business collaboration (Knowledge Economy Index, 2012). Another initiative is the Malaysia University English Test (MUET) launched in 2016, which recorded a 27.8\% rise in students obtaining better proficiency bands (Rahman, 2016). The government's initiatives whilst laudable, seems to be lagging in achieving its overall objectives of reducing graduate unemployment and enhancing English language proficiency, as was reported by Talent Corporation Malaysia (TalentCorp) in its article, 'Addressing Malaysia's Talent Shortages' (Shortage, 2017). The Department of Statistics reports that the country's unemployment rate is at $3.4 \%$ and that $26 \%$ of graduates are unemployed (Leo, 2018; Lim, 2018). Youth unemployment has hit an all-time high at $10.8 \%$, which is nearly three times the national unemployment rate (Department of Statistics Malaysia, 2018).

The Economic Planning Unit (EPU) recently revealed that a close proximate of 60,000 graduates are jobless, because of their lack of experience and poor English communication skills (Hassan, 2018). According to the Malaysian Employers Federation (2016), the Salary Surveys Report revealed that $90 \%$ of employers indicated the need for graduates to improve their English communication skills to be more employable. TalentCorp and the Institute of Labour Market Information \& Analysis (ILMIA) conducted a study in 2016, and found while there is a high demand for graduates who are proficient in English, the current supply is insufficient to meet the demand. In another survey carried out jointly by TalentCorp and the 


\section{Macrothink}

World Bank, 81 per cent of all respondents (employers) identify poor English communication skills as the main barrier in recruiting Malaysian graduates (The World Bank, 2015). Jobstreet Malaysia (2015), reported that a staggering 50 per cent of employers cited poor English communication as a key barrier to graduate employment. The National Higher Education Research Institute (IPPTN), indicated that Malaysian graduates are not proficient in the English language both written and spoken (Ismail, Yusoff, \& Sieng, 2011; Wei, 2011). Penang Research Institute (2016) in its report highlights that Malaysian graduates do not possess the type of skills demanded by employers, particularly English communication skills.

The scope of this study identifies 'English and communication skills' to include the ability to carry out formal presentations, writing of official communications, participating and contributing effectively as a team member and facilitating business meetings. English communication skills referred to in this paper comprise, oral and written communication, with the focus being on English proficiency. The findings of this study is a result of an investigation done through in-depth interviews on a cross-section of employers from key economic sectors to uncover and understand their expectations of graduates with regard to competency in English and communication skills and to discover ways to overcome this skill shortage.

The research objectives of this study are therefore two-fold:

\section{Research Objective 1}

To determine employers' expectations with regard to English proficiency and communication skills.

\section{Research Objective 2}

To explore ways to improve mastery of the English language and communication skills from the employers' perspective.

\section{Literature review}

\subsection{English Proficiency}

Competency in the English language is a necessary qualification and would be useful for workplace communication. From customer relationship management, to business development, to workplace conflict resolution (where the ability to express one's-self clearly is imperative), English communications skills are important. Employers actively lookout for graduates with good written and spoken English communication skills. Graduates who can communicate with clarity are assets to any organization (Robles, 2012). Good English proficiency is very important for jobs involving customer service, frontline customer support especially for globally-positioned companies. Malaysian employers expect employees to possess and demonstrate their English oral skill immediately upon employment (Priya, 2012). Hanapi and Nordin (2014) also reiterated that Malaysian employers expect employees to conduct meetings, interviews, and discussions in English. English proficiency is a critical success factor for employees in the private sector in Malaysia (Ting et al., 2017). Past research on graduate employability in Malaysia strongly indicate that graduates that seek 
employment need to be proficient in English (Marzuki et al., 2013).

\subsection{Communication Skills}

Without effective communication, a message may possibly turn into error, misunderstanding, or frustration, which could negatively impact the company's bottom-line. Communication is described as the exchange of information, feedback or response, ideas, and feelings. It provides knowledge, strengthens relationships, establishes predictable behaviour patterns, helps retain attention to the task at hand, and more importantly, it is a management tool (Dahunsi, 2017). Similarly, communication skills have been noted as essential for graduates and acknowledged as one of the strong employability factors by both academics and practitioners (Clokie \& Faurie, 2016). Employers consider good written and spoken communication as a key job qualifier (Hanapi \& Nordin, 2014; Seetha, 2014). Mazlan, Sui and Jano, (2013) and Monks (1997), underpin the importance of written communication and reiterate that it is a key success factor for new graduates. It underpins everything that an administrative team does by means of presenting a new strategy to motivate a team, manage or chair meetings (Garwood, 2012). Therefore, communication plays the critical role in an organization in connecting people, reducing confusion and enhances both efficiency and productivity among the staff members. Singh (2013), posits that the philosophies and values of top management are reflected in the way information flows in the organization.

\subsection{Employer Expectation}

Spoken and written communication in English, arithmetic and science were ranked as highly important for a new graduate to succeed in the workplace in Asia (Fearon et al., 2016). A study by Hamid, Islam and Hazilah (2014) in Malaysia showed that employers emphasise the importance of English communicative ability for graduate employability. The findings of the study rank the importance of key employability skills such as: 1) problem-solving skills, 2) teamwork skills, 3) time management skills, 4) English language proficiency, 5) information communication technology skills, and 6) leadership skills. In fact, employers in Malaysia prefer to hire private university graduates owing to their better English communication skills (Cheong et al., 2016). There is a gap between the skills needed by the employers and the skills that the new graduates are equipped with which is a big concern to the employers who are looking to hire competent workers (Gwyn, 2017). Research in this area suggests that that English language courses in Malaysian Universities are not adequately preparing graduates for the workplace (Kalaimagal \& Norizan, 2011). Pandey and Pandey (2014) postulated that an innovative employee with great ideas but poor English communication will find difficulty in advancing in the workplace. Dinning, (2017) highlighted a common complaint among employers about new hires, saying that they enter the workplace with sound knowledge on theories and principles but are poorly equipped with work-ready skills such as communication and interpersonal skills. 


\section{$\Lambda$ Macrothink}

\section{Methodology}

\subsection{Qualitative}

This research employed a qualitative approach to explore and interpret the data for an in-depth perspective of research problem (Blumberg et al., 2008). This approach additionally allows the researcher to determine clarity of the variable(s) for future evaluation. It also provides for adding depth to the phenomenon description through the viewpoints of the respondents (Tharenou, Donohue, \& Cooper, 2007). The qualitative inquiry is usually carried out by undertaking in-depth interviews and focus group sessions in uncovering answers to 'why and how' questions in any research (Bryman \& Bell, 2011).

\subsection{Sampling and Data Collection}

This research was exploratory and therefore it was necessary to collect a wide range of data with the respondents representing a diverse background (Creswell \& Plano Clark, 2017; Saldana, 2011). In view of this, undertaking a purposeful sampling technique, using non-probability method was regarded as the most suitable approach for a naturalistic enquiry in recruiting the respondents. Purposeful sampling uses a group sample chosen based on their knowledge and experience in a phenomenon of interest (Creswell \& Plano Clark, 2011). The selection criteria were based on relevant working experience in leadership, with hands-on management of graduates in a cross-section of varied economic sectors.

Malaysia's Critical Occupation List (COL) (2017), identifies 17 key economic sectors, where skill shortage was highlighted. A single participant was selected from each of those sectors for the interviews. Qualitative research methodology does not require a large sample, therefore semi-interviews were carried out until saturation in responses of the informants were detected (Denzin \& Lincoln, 2017; Cobin \& Strauss, 1998). Along the process of the interviews, repeating themes were identified from the $8^{\text {th }}$ participant onwards. Upon closer inspection of the research data, no new themes emerged in the $9^{\text {th }}$ and $10^{\text {th }}$ interviews, thus indicating that saturation is deemed to have taken place thereon from the $8^{\text {th }}$ interview.

\subsection{Data Analysis}

Interviews were digitally recorded and transcribed and this helped the researchers to code major themes independently by employer. The vast volume of data was then put through the reduction process, which enabled the consolidation of overlapping themes. The interview files were saved in MS Word and then subsequently uploaded into ATLAS.ti which is a $C A Q D A S$. This method of organisation of a large volume of data made it easy for the researcher to then manually read and re-read, noting themes and assigning these themes with code names and code colour using the functions available in ATLAS.ti. Saldana (2011) and Patton (2014) strongly support the use of thematic analysis as for a rich and complete analysis especially in the fields of business and social science.

\subsection{Participant Description}

As noted, 10 respondents participated in in-depth interviews. Pseudonyms are used throughout the discussion of findings for confidentiality (Kaiser, 2009). Table 1 in the 


\section{Macrothink}

International Journal of Learning and Development

ISSN 2164-4063 2020, Vol. 10, No. 3

following page, presents the profile of respondents that participated in the in-depth interviews.

Table 1. In-depth interview respondent description

\begin{tabular}{|c|c|c|c|c|c|c|}
\hline No & Pseudonyms & Position & Profile & $\begin{array}{c}\text { No. of } \\
\text { employees }\end{array}$ & $\begin{array}{l}\text { Nature of } \\
\text { Business }\end{array}$ & $\begin{array}{l}\text { Key economic } \\
\text { sectors }\end{array}$ \\
\hline 1 & A & CEO & $\begin{array}{c}\text { Female, } 48 \\
\text { Business } \\
\text { owner and } \\
\text { entrepreneur }\end{array}$ & 42 & $\begin{array}{c}\text { Media and } \\
\text { publications }\end{array}$ & $\begin{array}{c}\text { Arts, } \\
\text { Entertainment } \\
\text { and Recreation }\end{array}$ \\
\hline 2 & $\mathrm{~B}$ & CEO & $\begin{array}{c}\text { Male, } 62 . \\
\text { Business } \\
\text { owner and } \\
\text { entrepreneur }\end{array}$ & 35 & $\begin{array}{l}\text { Information } \\
\text { Technology }\end{array}$ & $\begin{array}{c}\text { Information } \\
\text { and } \\
\text { Communication }\end{array}$ \\
\hline 3 & $\mathrm{C}$ & CEO & $\begin{array}{l}\text { Male, } 42 . \\
\text { Business } \\
\text { owner }\end{array}$ & 30 & Engineering & $\begin{array}{l}\text { Scientific and } \\
\text { Techinical } \\
\text { Activities }\end{array}$ \\
\hline 4 & $\mathrm{D}$ & Manager & $\begin{array}{c}\text { Male, } 47 \\
\text { Accountant } \\
\text { and } \\
\text { Manager }\end{array}$ & 120 & $\begin{array}{l}\text { Accounting } \\
\text { and Taxation }\end{array}$ & $\begin{array}{l}\text { Professional } \\
\text { Services }\end{array}$ \\
\hline 5 & $\mathrm{E}$ & $\begin{array}{c}\text { Vice } \\
\text { President }\end{array}$ & $\begin{array}{l}\text { Male, } 59 \\
\text { Division } \\
\text { Head }\end{array}$ & 3000 & $\begin{array}{l}\text { Banking and } \\
\text { Finance }\end{array}$ & $\begin{array}{l}\text { Financial and } \\
\text { Insurance }\end{array}$ \\
\hline 6 & $\mathrm{~F}$ & $\begin{array}{c}\text { Head of } \\
\text { Department }\end{array}$ & $\begin{array}{c}\text { Female, } 36 \\
\text { Manager }\end{array}$ & 350 & Education & Education \\
\hline 7 & G & $\begin{array}{l}\text { Managing } \\
\text { Partner }\end{array}$ & $\begin{array}{c}\text { Male, } 46 \\
\text { Business } \\
\text { owner and } \\
\text { manager }\end{array}$ & 55 & $\begin{array}{l}\text { Training and } \\
\text { Development }\end{array}$ & $\begin{array}{l}\text { Support } \\
\text { Services }\end{array}$ \\
\hline 8 & $\mathrm{H}$ & $\mathrm{CEO}$ & Male, 49 & 150 & Pharmaceutical & $\begin{array}{l}\text { Human Health } \\
\text { Activities }\end{array}$ \\
\hline 9 & $\mathrm{~J}$ & $\begin{array}{l}\text { Hiring } \\
\text { Manager }\end{array}$ & $\begin{array}{l}\text { Female, } 35 \\
\text { Hiring } \\
\text { manager }\end{array}$ & 500 & Automobile & Manufacturing \\
\hline 10 & $\mathrm{~K}$ & Head & $\begin{array}{l}\text { Human } \\
\text { resource } 42\end{array}$ & 2500 & Brewery & $\begin{array}{l}\text { Food and } \\
\text { Beverage }\end{array}$ \\
\hline
\end{tabular}




\section{Macrothink}

\section{Findings}

The interview findings offered much clarity and reasons contributing to the graduate employability problem in Malaysia. The high unemployment rate summates to one key factor, which is a lack of soft skills specifically the inadequate command of English communication skills. Additionally, a lack of proficiency in English will undoubtedly affect one's self-confidence during an interview. Therefore, the key findings that emerged from the in-depth interviews in exploring perceptions of the employers on English communication skills will be analysed and presented according to each Research Objective.

\subsection{Research Objective 1}

It was evident from the findings from the employer perspective, English communication skills were given the highest priority. Munro (2017), identified 10 key soft skills needed at the workplace, with verbal and written communication as the top two most important skills for graduates. From the qualitative findings and also from existing literature, the employer viewpoint has always emphasised English communication as the most desired soft skill when recruiting graduates. Below are some employer narratives from the in-depth interviews of this study, which reiterate the importance of English communication.

\section{D; ATLAS.ti Code 9:1}

English proficiency and communication is very important. Think about the reports that we write, letters, emails, memos that go out on a daily basis. It affects our image and standards

E; ATLAS.ti Code 10:1

It's very important to communicate with everyone in the office sometimes through presentations and sometimes through emails and memos. English proficiency and communication are key in this case...... and in a service industry, communication and interpersonal skills are very important.

\section{F; ATLAS.ti Code 3:1}

We need our candidates to demonstrate high level of English communication; both written and oral. If they cannot demonstrate this at the interview, we do not hire them even if they have a PhD.

\section{G; ATLAS.ti Code 11:1}

Speaking, listening, writing and presentation in English are important. It is important to listen and understand ...(we) need to listen to the client in order to provide them the solution they need and then be able to present those solutions in the most impeccably clear way.

\section{K; ATLAS.ti Code 5:1}

Communicating in good English is the most important soft skill for a graduate to have. I mean, everything at work eventually boils down to the ability to communicate. If you have a great idea, you need to be able to speak and write about it clearly. If you have a great product, you need to be able to communicate the benefits of it to the customer. 


\section{Macrothink}

International Journal of Learning and Development

ISSN 2164-4063

2020, Vol. 10, No. 3

From the excerpts above, it is clear that employers place a high value on graduates who have good command of the English language and also good communication skills.

\subsection{Research Objective 2}

The interview transcripts were coded according to themes three new themes were identified and are presented in Table 2 in the following page with key words from the quotations.

Table 2. Thematic analysis

\section{Themes}

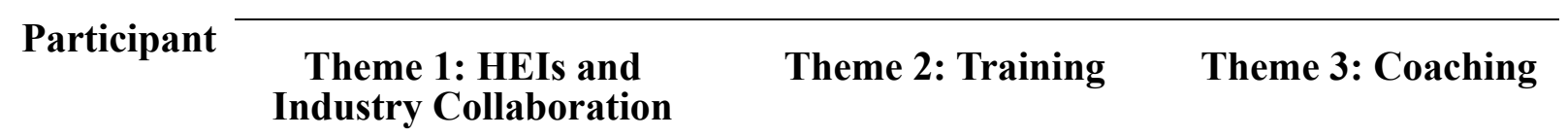

Key Words

\begin{tabular}{cc}
\hline A work closely together & $\begin{array}{c}\text { Training Course in } \\
\text { Business Communication }\end{array}$ \\
\hline B & $\begin{array}{c}\text { in-house English language } \\
\text { program }\end{array}$ \\
\hline
\end{tabular}

\begin{tabular}{|c|c|c|}
\hline $\mathrm{C}$ & Engage trainers & $\begin{array}{l}\text { senior staff mentor } \\
\text { the new graduates }\end{array}$ \\
\hline $\mathrm{D}$ & & $\begin{array}{l}\text { a lot of effort to } \\
\text { coach and support } \\
\text { them }\end{array}$ \\
\hline
\end{tabular}

\begin{tabular}{ll}
\hline $\mathrm{E}$ & $\begin{array}{c}\text { coaching help them } \\
\text { with their skills }\end{array}$ \\
\hline $\mathrm{F}$ & play an active role \\
\hline $\mathrm{G}$ & $\begin{array}{c}\text { create more business } \\
\text { relevant subjects. }\end{array}$ \\
\hline
\end{tabular}
$\mathrm{H} \quad$ Corporate leaders involved weekly class: Speak well, in curriculum design be understood

\begin{tabular}{|c|c|}
\hline $\mathrm{J}$ & $\begin{array}{l}\text { Coaching highly } \\
\text { successful }\end{array}$ \\
\hline
\end{tabular}

K $\quad \begin{array}{cc}\text { Industry Advisory } \\ \text { Committee taken seriously }\end{array} \quad \begin{gathered}\text { English and presentation } \\ \text { training }\end{gathered}$




\section{Macrothink}

\subsubsection{HEIs and Industry Collaboration}

Presently, Malaysia's innovative capability through HEI and business collaboration is reported to demonstrate a notable gap with high-income nations. According to The World Bank's Knowledge Economy Index, Malaysia ranks 48 out of 145 countries in innovative capability approximately the same as it faired two decades ago (World Bank Group, 2018). One key factor is attributed to the lack of HEI and business collaboration and another is insufficient manpower for R\&D activities (Govindaraju \& Wong, 2011). Evidently, there is an urgent need for broader and a more intensive dialogue between employers, graduates and HEIs. Participants A, F, G and H and K strongly echoed this view. The excerpts are presented below:

\section{A; ATLAS.ti Code 7:1}

Universities and us business leaders need to work closely together to find a solution

\section{F; ATLAS.ti Code 3:2}

Industry Advisory Panels need to play an active role ....we have obligatory meetings, but the Universities are reluctant to incorporate suggestions because it requires too much paper work to revamp the syllabus.

\section{G; ATLAS.ti Code 11:2}

We would really like to get involved and help create more business relevant subjects.

\section{H; ATLAS.ti Code 1:1}

Some of the subjects being taught are the same as what I did when I was in university 20 years ago. It is not relevant anymore. We as corporate leaders should be involved in curriculum design

\section{K; ATLAS.ti Code 5:2}

Universities need to take the role of the Industry Advisory Committees seriously and listen to what we have to say

\subsubsection{Training}

Five out of ten participants of the interview identified training for graduates as being an effective method to overcome the English communication skills deficit of graduates. This was reflected in their responses during the interviews. Participants saw training as a necessary pre-requisite for enhancement of graduates' English communication. Participants A, B, C, H and K strongly support this view. The excerpts are presented below:

\section{A; ATLAS.ti Code 7:2}

"It pains me to see how poor our graduates are in communicating in English. I got so tired of hiring them and then having to speak to clients myself that, I now put in place a Training Course in Business Communication, which I conduct myself. It's an ongoing course that spans one year. So, 2 classes every month and a test at the end of that. This has helped keep 
customer complaints down and I see a big improvement"

\section{B; ATLAS.ti Code 8:1}

I don't understand why their English is so bad. What do they teach them in school? So all my new hires have to do an English language test upon recruitment and then based on their performance they have to attend an in-house English language program. There are few levels depending on how good or bad you are. This helps a lot. I spend less time now correcting their emails.

\section{C; ATLAS.ti Code 2:1}

We engage external trainers to do the job of training the young graduates. Its not that they have bad English, its just that they don't know how to communicate their ideas clearly.

\section{H; ATLAS.ti Code 1:2}

We are a very sales driven company and our clients are doctors and hospital administrators. They are highly qualified and senior members of the medical profession. So naturally English language and communication is key to closing a sale. So all our new recruits go through English and presentation training.

\section{K; ATLAS.ti Code 5:3}

We are a multinational company so English and communication is very important. We have an English test at the point of the interview, where they have to write a prose of 100 words on why we should hire them. They also have to do a 10minute presentation on any topic of their choice. We also run a weekly class every Friday titled: Speak well, be understood. We engage external consultants to run the program in the hope of improving our graduates.

The five participants concurred graduate training in English communication as an important element to improve graduate employability. While asserting the importance of training they also felt that graduate training is an enabler in professional development. The training construct is a critical discovery as it indicates the willingness of the employers to undertake the responsibility of training the graduates to acquire the skills required to succeed (Crebert et al., 2004; Winstead, Adams, \& Sillah, 2011).

\subsubsection{Coaching}

The interviews also revealed the significant role coaching plays in helping the new graduate acquire better English proficiency and communication skills. The participants shared that coaching programs help improving employee retention, turnover and career advancement. The findings of this research are consistent to that of Chang and Busser (2017), which posits that coaching improves manpower retention, job satisfaction and leadership development in today's more competitive and global markets. A survey conducted in 2017 revealed that $71 \%$ of Fortune 500 companies offer coaching programs, which is becoming more widely practiced in many workplaces (Kantor, 2017). Coaching was recommended by four out of the ten employers interviewed as a tool in developing communicative ability in the new hires especially in English. The one-on-one discussions and planning and coaching were in their 
words 'more permanent' with 'sustainable results'. Participants C, D, E and J strongly agree with this view. Excerpts of their views are provided below:

\section{C; ATLAS.ti Code 2:2}

We are in the business of customizing telecommunications solutions for our customers. So clarity is important. We need to know what the customers want exactly. This requires a lot of strategizing, discussion and planning. This gives the senior staff member opportunities to coach the new graduates, always keeping the medium of communication in English. Within a year or so you see a big difference in their level of confidence.

\section{D; ATLAS.ti Code 9:2}

Customers can be very demanding, so we need to be able to handle them with tact. Naturally English proficiency is very important. We have to present and negotiate and problem-solve for our customers. I don't let them (new graduates) go solo immediately. They have to 'shadow' me or another partner assigned to mentor them for about 6 months... during which time we actually put in a lot of effort to mentor and teach them. You see big improvements in them especially after 1 or 2 years.

\section{E; ATLAS.ti Code 10:2}

As a large banking and financial institution, English language proficiency is a non negotiable attribute. We have to coach the young ones, otherwise how will they learn. From young their communication has always been mostly via digital communication so coaching is a very good way to help them with their interpersonal skills.

\section{J; ATLAS.ti Code 6:1}

Coaching has long-term improvements, so we practice this in our office formally. We structure it into staff KPI. A junior staff is assigned to a high performing senior staff and the junior staff performance improvement can be monitored. It's a highly successful system with sustainable results.

\section{Discussions and Recommendations}

Graduates must realize that in order to be employable they should match employer needs. In exploring employers' perspectives in this study, all were congruent that graduates who wish to be employable and advance in their jobs must have strong English communication skills. In view of this expectation the responsibility falls on the relevant stakeholders to contribute to empowering the new graduates in this area.

\subsection{Stronger Bilateral Interaction Between Industry and HEIS}

Mazlan, Sui, and Jano (2013) and Seetha (2014), posited that the Malaysian HEIs are not able to prepare graduates to have the necessary English communication skills needed at the workplace. The suggestion was to consider employing different teaching methods and English syllabus that is relevant to the needs of the business community. Current literature provides strong evidence to indicate the strategic importance of HEIs and business 
collaboration and how this has a powerful influence on national economies (Hatakenaka, 2015; Tran, 2016). HEIs and business research collaboration has been found to be a catalyst for productivity, growth and competitiveness (Tran, 2016).

In view of this, HEIs should develop strategic initiatives to foster collaborative relationships with research institutions, foreign universities and the industry to strengthen R\&D activities. This study proposes to achieve this through the following:

a) Firstly, to implement attachment programs within the industry, which will enable lecturers to share their knowledge and ideas and thus raise the quality of their research.

b) Secondly, to set an organized repository system to better manage intellectual property developed in HEIs in order to improve the governance of research activities.

c) Thirdly, to strengthen the role of the Industry Advisory Panel at HEIs (Salleh \& Omar, 2013).

\subsection{Training}

The findings from the interviews offered the view that many graduates are left 'unemployed' as a result of being unable to demonstrate adequate communication skills in English. The key findings that emerged from the in-depth interviews to overcome this skill deficit are through graduate training and coaching.

Ismail (2011) states that businesses in Malaysia are arduously seeking graduates who have good English communication skills. However, teachers in schools approach teaching English as a 'language' rather than a 'communicative tool' (Beresova, 2016). The author argues that when the English language is delivered through this approach, learners from non-English speaking homes, develops a fear of the language which hinders the learning cycle. Participant B made a similar comment (ATLAS.ti Code 8:2)

I keep the process open and non-threatening, so they feel free enough to ask questions whenever in doubt. I think the atmosphere of coaching is so important. No one can learn underfear.

Thus the employees should not be bound by constraints of a fear-driven, structured syllabus as is the approach taken by HEIs and schools. A student-friendly approach of active workshops, impromptu speeches and business-type presentations is recommended. By implementing English training programs through this approach, knowledge and skills can be shared between employers and employees. Successful transfer of skills leads to the development of the competency of workers (El-Temtamy et al., 2016). Nagarajan and Edwards (2015), claim that the transfer of knowledge and skills prepares employees to be competitive in the challenging job market.

\subsection{Coaching}

The interviews revealed the importance of coaching of a new graduate by a senior employee. The participants shared that coaching programs are becoming increasingly popular in workplaces, as they help in reducing turnover, promoting growth, and help employees adjust 
to new positions as well as become prepared for career advancement. This finding is consistent with Chang and Busser (2017). Coaching has long been regarded as an effective means of cultivating good practice in work settings (Darwin, 2015). In contemporary business setting, researchers support the notion that having mentors increases one's chance of leadership success and the benefits of coaching have been articulated by a number of studies since the late 1970s (Darwin, 2015; Raggins \& Kram, 2007).

Employers therefore need to design a coaching system as part of the workplace system and culture towards being a learning organisation. Comments from $\mathrm{J}$, hiring manager of a multinational automobile confirmed this as follows:

We do have a 'Buddy' system, where we pair up a new graduate appointee with a high performing senior employee. The coaching is for 6 months and we have a formal structure and process how it is done. (ATLAS.ti Code 6:2)

Similar sentiments on a formalised coaching structure were echoed by D:

I believe that every senior member should undertake to mentor new graduates. Our company makes coaching as one of the senior member's KPI to improve the new employee not only in English language but other transferable skills as well. (ATLAS.ti Code 9:3)

\section{Conclusion}

The findings of this study address a key concern of the Malaysian government in identifying shortages in economic sectors that are associated with Malaysia's growing knowledge-based economy. Therefore it is important to determine whether there are mismatches between employers' demand and the supply of the skills associated with these demands. As a result, this study identifies English proficiency and communication skills as vital and sought after by employers. The findings of this study also help policymakers with decisions consistent with Malaysia's strategic economic development objectives.

It is therefore critical that HEIs redesign undergraduate curricula to reflect this fact and include English language and communication as a vital components in their student programmes. These courses should be developed to generate vital outcomes including speaking English with confidence, being able to carry out professional presentations and having the ability to write with the correct grammar and syntax. HEIs must work towards creating an English-speaking environment as opposed to one limited to their own ethnic languages. In this regard, the findings also strongly encourage stronger bilateral interactions between the business community and the HEIs. This will ensure that the redesigning of curricula will aim towards preparing students for the workplace. Assessments should include tasks performed during employment to provide students with hands-on experience while giving them an avenue to apply the theories learnt.

The findings also uncovered the role played by the business community in the private sector. The private sector has already begun to undertake its own remedial measure, which include implementation of in-house graduate training specifically focussed on the English language. Participants of this study strongly opined that this initiative through language classes, 
presentation workshops and programmes assessed internally, would yield desired outcomes. Coaching was also recommended as a valuable investment and described as 'ensuring more permanent and sustainable' results. The findings, if implemented, will work towards creating university graduates who will be better prepared for the workplace, thereby increasing their employability in the highly competitive global market.

\section{References}

Alias, N. (2017). Making Graduate More Employable. The Edge Markets. Retrieved from http://www.theedgemarkets.com/article/my-say-making-graduates-more-employable

Beresova, J. (2016). Contemporary English - a challenge for non-native speakers. Global Journal Of Foreign Language Teaching, 6(2), 85. https://doi.org/10.18844/gjflt.v6i2.570

Blumberg, B., Cooper, D., \& Schindler, P. (2008). Business research methods. London: McGraw-Hill Higher Education.

Bryman, A., \& Bell, E. (2011). Business research methods. Oxford: Oxford University Press.

Chang, W., \& Busser, J. (2017). Hospitality employees promotional attitude: Findings from graduates of a twelve-month management training program. International Journal of Hospitality Management, 60, 48-57. https://doi.org/10.1016/j.ijhm.2016.09.013

Cheong, K., Hill, C., Fernandez-Chung, R., \& Leong, Y. (2015). Employing the 'unemployable': employer perceptions of Malaysian graduates. Studies In Higher Education, 41(12), 2253-2270. https://doi.org/10.1080/03075079.2015.1034260

Chipman, R. (2018). The Real Cost of Expatriate Assignment Failure Asian Tigers Mobility. $\begin{array}{llll}\text { Retrieved } 17 \quad \text { June } & \text { 2018, from }\end{array}$ https:/www.asiantigers-mobility.com/the-real-cost-of-expatriate-assignment-failure/

Clokie, T., \& Fourie, E. (2016). Graduate Employability and Communication Competence. Business And Professional Communication Quarterly, 79(4), 442-463. https://doi.org/10.1177/2329490616657635

Crebert, G., Bates, M., Bell, B., Patrick, C., \& Cragnolini, V. (2004). Developing generic skills at university, during work placement and in employment: graduates' perceptions. Higher Education Research \& Development, 23(2), 147-165. d https://doi.org/10.1080/0729436042000206636

Creswell, J., \& Plano Clark, V. (2017). Designing and conducting mixed methods research (3rd ed., p. 67). Designing and Conducting Mixed Methods Research.

Dahunsi, T. (2017). Graduate Employability and Communication Skills: An Investigation of Nigerian Graduates' Proficiencies and Areas of Deficiencies in Written English. World Journal Of English Language, 7(3), 49. https://doi.org/10.5430/wjel.v7n3p49

Denzin, N., \& Lincoln, Y. (2018). The Sage handbook of qualitative research. Los Angeles: SAGE. 


\section{Macrothink}

International Journal of Learning and Development

ISSN 2164-4063

2020, Vol. 10, No. 3

Department of Statistics. (2015). Labour Force Survey Report. Kuala Lumpur: Department of statistics.

Retrieved

from

https://www.statistics.gov.my/dosm/index.php?r=column/ctheme\&menu

Department of Statistics Malaysia. (2018). Key Statistics of Labour Force in Malaysia, January 2018 (p. 1). Kuala Lumpur: Department of Statistics Malaysia.

Dinning, T. (2017). Preparing sports graduates for employment: satisfying employers expectations. Higher Education, Skills And Work-Based Learning, 7(4), 354-368. https://doi.org/10.1108/HESWBL-02-2017-0017

Dowling, P., \& Welch, D. (2004). International human resource management. London: Thomson Learning.

Dowling, P., Festing, M., \& Engle, A. (2017). International human resource management. Australia: Cengage Learning.

EF English Proficiency Index. (2018). EF English Proficiency Index-Malaysia. Zurich: EF EPI. Retrieved from https://www.ef.com/wwen/epi/about-epi/

El-Temtamy, O., O’Neill, K., \& Midraj, S. (2016). Undergraduate employability training and employment: a UAE study. Higher Education, Skills And Work-Based Learning, 6(1), 100-115. https://doi.org/10.1108/HESWBL-02-2015-0006

Employers: Fresh Graduates Have Unrealistic Expectations JobStreet. Malaysia. (2015). Retrieved June 13, 2018, from https://www.jobstreet.com.my/career-resources/employers-fresh-graduates-unrealistic-expect ations/

Fearon, C., Nachmias, S., McLaughlin, H., \& Jackson, S. (2016). Personal values, social capital, and higher education student career decidedness: a new 'protean'-informed model. Studies In Higher Education, 269-291. https://doi.org/10.1080/03075079.2016.1162781

Finch, D., Hamilton, L., Baldwin, R., \& Zehner, M. (2013). An exploratory study of factors affecting undergraduate employability. Education Training, 55(7), 681-704. https://doi.org/10.1108/ET-07-2012-0077

Garwood, R. (2012). Supporting the underperforming manager. Human Resource Management International Digest, 20(1), 39-42. https://doi.org/10.1108/09670731211195963

Govindaraju, C., \& Wong, C. (2011). Patenting activities by developing countries: The case of Malaysia. World Patent Information, 33(1), 51-57. https://doi.org/10.1016/j.wpi.2010.01.001

Gwyn, M. (2017). Incorporating Employer and Student Assessment Into a Graduate Attribute Assessment Plan. Proceedings Of The Canadian Engineering Education Association. https://doi.org/10.24908/pceea.v0i0.6486

Hamid, M., Islam, R., \& Hazilah, A. (2014). Malaysian graduates’ employability skills 
enhancement: an application of the importance performance analysis. Journal For Global Business Advancement, 7(3), 181. https://doi.org/10.1504/JGBA.2014.064078

Hanapi, Z., \& Nordin, M. (2014). Unemployment among Malaysia Graduates: Graduates'Attributes, Lecturers' Competency and Quality of Education. Procedia-Social And Behavioral Sciences, 11(2), 1056-1063. https://doi.org/10.1016/j.sbspro.2014.01.1269

Harzing, A., \& Pinnington, A. (2015). International human resource management. London: Sage.

Hassan, A. (2018). Internship Framework Guidelines for Malaysian Public Higher Education Institutes. Journal Of Science Technology And Innovation Policy, 4(1), 20-28.

Hatakenaka, S. (2015). The Role of Higher Education Institutions in Innovation and Economic Development. International Higher Education, (47). https://doi.org/10.6017/ihe.2007.47.7961

Hoe, P., \& Jangwan, K. (2016). Relationship between Collaborative Self-efficacy and Problem-solving Skills of University Students: Mediating Effect of Communication Skills. Journal Of Educational Innovation Research, 26(1), 169-192. https://doi.org/10.21024/pnuedi.26.1.201604.169

Ismail, I. (2011). Graduates' Characteristics and Unemployment: A Study Among Malaysian Graduates. International Journal Of Business And Social Science, 2(6).

Ismail, R., Yussof, I., \& Sieng, L. (2011). Employers' Perceptions on Graduates in Malaysian Services Sector. International Business Management, 5(3), 184-193. https://doi.org/10.3923/ibm.2011.184.193

Kaiser, K. (2009). Protecting Respondent Confidentiality in Qualitative Research. Qualitative Health Research, 19(11), 1632-1641. https://doi.org/10.1177/1049732309350879

Kalaimagal, R., \& Norizan, M. (2011). Employment issues among Malaysian Information and Communication Technologies (ICT) graduates: A case study. African Journal Of Business Management, 5(26), 10855-10861. https://doi.org/10.5897/AJBM11.811

Kantor, J. (2017). Four Key Benefits of Workplace Mentoring Initiatives. Retrieved June 13, 2018 , from http://www.huffingtonpost.com/julie-kantor/four-key-benefits-of-work_b_9432716.html

Key Statistics of Labour Force in Malaysia, January 2018. (2018). Retrieved February 12, 2019,

from https://www.dosm.gov.my/v1/index.php?r=column/pdfPrev\&id=aUVrUWh2ZnZubkl2RUxE QU15N3ZWdz09

Kirkpatrick, A. (2012). English in ASEAN: implications for regional multilingualism. Journal Of Multilingual And Multicultural Development, 33(4), 331-344. https://doi.org/10.1080/01434632.2012.661433

Knowledge Economy Index (World Bank). (2012). Retrieved February 12, 2019, from 


\section{Macrothink}

International Journal of Learning and Development

ISSN 2164-4063 2020, Vol. 10, No. 3

https://datasource.kapsarc.org/explore/dataset/knowledge-economy-index-world-bank-2012/i nformation/

Leo, M. (2018). Fresh Graduate Unemployment in Malaysia EduAdvisor. Retrieved February 12, 2019, from https://eduadvisor.my/articles/what-didnt-know-fresh-graduate-unemployment-malaysia-info graphic/

Lim, C. (2018). New jobs taken by foreigners as graduate unemployment rises. Retrieved February 12, 2019, from http://www.theedgemarkets.com/article/new-jobs-taken-foreigners-graduate-unemployment-r ises

Malaysia's Critical Occupations List. (2017). Retrieved February 3, 2019, from https://www.talentcorp.com.my/key-figures/malaysias-critical-occupations-list

Malaysian Employers Federation. (2016). English Proficiency Critical to Enhance Employability of Graduates. Retrieved from http://www.mef.org.my/news/pr_article.aspx?@ID=20

Marzuki, E., Ting, S., Jerome, C., Chuah, K., \& Misieng, J. (2013). Congruence between Language Proficiency and Communicative Abilities. Procedia-Social And Behavioral Sciences, 97, 448-453. https://doi.org/10.1016/j.sbspro.2013.10.258

Matsouka, K., \& Mihail, D. (2016). Graduates' employability. Industry And Higher Education, 30(5), 321-326. https://doi.org/10.1177/0950422216663719

Mazlan, K., Sui, L., \& Jano, Z. (2015). Designing an Eportfolio Conceptual Framework to Enhance Written Communication Skills among Undergraduate Students. Asian Social Science, 11(17). https://doi.org/10.5539/ass.v11n17p35

Mendenhall, M., Dunbar, E., \& Oddou, G. (1987). Expatriate Selection, Training and Career-Pathing: A Review and Critique. Human Resource Management, 26(3), 331-345. https://doi.org/10.1002/hrm.3930260303

Monks, K. (1997). Enhancing the written communication skills of undergraduate students. Education Training, 39(1), 36-39. https://doi.org/10.1108/00400919710157150

Munro, E. (2017). Building soft skills in the creative economy: Creative intermediaries, business support and the 'soft skills gap". Poetics, 64, 14-25. https://doi.org/10.1016/j.poetic.2017.07.002

Nagarajan, S., \& Edwards, J. (2015). The Role of Universities, Employers, Graduates and Professional Associations in the Development of Professional Skills of New Graduates. Journal Of Perspectives In Applied Academic Practice, 3(2). https://doi.org/10.14297/jpaap.v3i2.137

National Association of College Education United Kingdom. (2009). Job Outlook 2009 Study. London: Ministry of Education UK. Retrieved from 
http://www.naceweb.org/press/display.asp?year=2009\&prid=295

Panahi, S. (2016). Predictors of Psychological Well-being among Malaysian Graduates. The European Journal Of Social And Behavioural Sciences, 16(2), 2067-2083. https://doi.org/10.15405/ejsbs.186

Pandey, M., \& Pandey, P. (2014). Better English for better employment opportunities. International Journal Of Multidisciplinary Approach And Studies, 1(4), 93-100.

Park, E., \& Spolsky, B. (2017). English education at the tertiary level in Asia (pp. 109-129). Abingdon: Routledge. https://doi.org/10.4324/9781315391588

Patton, M. (2014). Qualitative evaluation and research methods. London; Newbury Park; New Delhi: Sage Publications.

Penang Research Institute. (2016). Malaysia's Labour Market and Job Creation under the Economic Transformation Program (ETP) 2011 to 2015. (p. 32). Penang: Penang Research Institute. Retrieved from http://penanginstitute.org/v3/files/research_papers/Malaysia_s-labour-market-and-job-creatio n-under-the-ETP

Priya, C. (2012). The Role of English Language in Human Resource Management and Employability. International Journal Of Scientific Research, 3(4), 143-144. https://doi.org/10.15373/22778179/APR2014/218

Puteh, A. (2010). The Language Medium Policy in Malaysia: A Plural Society Model? Review Of European Studies, 2(2). https://doi.org/10.5539/res.v2n2p192

Ragins, B., \& Kram, K. (2007). The handbook of mentoring at work. Los Angeles (Calif): Sage Publications.

Rahman, D. (2016). Making Malaysian graduates more employable a reality-What's Your Status? Retrieved $\quad$ February $12, \quad 2019$, from https:/www.thestar.com.my/opinion/online-exclusive/whats-your-status/2016/07/14/makingmalaysian-graduates-more-employable/

Robles, M. (2012). Executive Perceptions of the Top 10 Soft Skills Needed in Today's Workplace. Business Communication Quarterly, 75(4), 453-465. https://doi.org/10.1177/1080569912460400

Sachdeva, S., \& Malhotra, K. (2014). Motivating Students - Essentials of Mentoring, Coaching \& Counseling: Operational Strategy. Issues And Ideas In Education, 2(2), 273-300. https://doi.org/10.15415/iie.2014.22020

Saldaña, J. (2011). Fundamentals of qualitative research. New York: Oxford University Press.

Salleh, M., \& Omar, M. (2013). University-industry Collaboration Models in Malaysia. Procedia-Social and Behavioral Sciences, 102, 654-664. https://doi.org/10.1016/j.sbspro.2013.10.784 
Seetha, N. (2014). Are Soft skills Important in the Workplace? â A Preliminary Investigation in Malaysia. International Journal Of Academic Research In Business And Social Sciences, 4(4). https://doi.org/10.6007/IJARBSS/v4-i4/751

Shortages, T. (2017). TalentCorp: Critical Occupations List: Addressing Malaysia's Talent Shortages Leaderonomics.com. Retrieved June 13, 2018, from https://leaderonomics.com/business/talent-shortages-in-malaysia

Singaravelu, G., \& Paramasivam, M. (2016). Insight Of Teachers On Problems Of Students In Acquiring Communicative Skill In English. I-Manager'S Journal On English Language Teaching, 6(2), 9. https://doi.org/10.26634/jelt.6.2.5977

Singh, J. (2013). Achieving Sustainability Through Internal Communication and Soft Skills. Asia Pacific Institute Of Management, 7(1), 21-26.

Tharenou, P., Donohue, R., \& Cooper, B. (2007). Management research methods. Cambridge [England]: Cambridge University Press. https://doi.org/10.1017/CBO9780511810527

The World Bank. (2015). Towards a Middle-Class Society. Kuala Lumpur, Malaysia: The World Bank Group. Retrieved from http://www.worldbank.org/en/country/malaysia/publication/malaysia-economic-monitor-dece mber-2014-towards-a-middle-class-society

Thomas, A., Piquette, C., \& McMaster, D. (2016). English communication skills for employability: the perspectives of employers in Bahrain. Learning And Teaching In Higher Education: Gulf Perspectives, 13(1). https://doi.org/10.18538/lthe.v13.n1.227

Ting, S., Marzuki, E., Chuah, K., Misieng, J., \& Jerome, C. (2017). Employers' Views on Importance of English Proficiency and Communication Skill for Employability in Malaysia. Indonesian Journal Of Applied Linguistics, 7(2), 77. https://doi.org/10.17509/ijal.v7i2.8132

Tran, T. (2016). Enhancing graduate employability and the need for university-enterprise collaboration. Journal Of Teaching And Learning For Graduate Employability, 7(1), 58. https://doi.org/10.21153/jtlge2016vol7nolart598

Truong, T., Laura, R., \& Shaw, K. (2018). The Importance of Developing Soft Skill Sets for the Employability of Business Graduates in Vietnam: A Field Study on Selected Business Employers. Journal Of Education And Culture Studies, 2(1), 32. https://doi.org/10.22158/jecs.v2n1p32

Winstead, A., Adams, B., \& Sillah, M. (2011). Teaching The Soft Skills: A Professional Development Curriculum To Enhance The Employability Skills Of Business Graduates. American Journal Of Business Education (AJBE), 2(5). https://doi.org/10.19030/ajbe.v2i5.4068

World Bank Group. (2018). The Challenges of Malaysia's Transition into a High Income Country. Kuala Lumpur, Malaysia: World Bank Group-Global Knowledge and Research Hub. Retrieved from http://documents.worldbank.org/curated/en/185861527855417221/pdf/126781-WP-PUBLIC- 


\section{Macrothink}

P160562-World-Bank-Report-08-Productivity-Unp

\section{Copyright Disclaimer}

Copyright for this article is retained by the author(s), with first publication rights granted to the journal.

This is an open-access article distributed under the terms and conditions of the Creative Commons Attribution license (http://creativecommons.org/licenses/by/4.0/). 